\title{
Two Poorly Known Species of Salticid Spiders from Japan
}

\author{
Hiroyoshi IKEDA $^{1)}$
}

池田博明 ${ }^{1)}$ :日本産ハエトリグモ科のよく知られていない 2 種

\begin{abstract}
Two species of salticid spiders, Bristowia heterospinosa ReIMOSER, 1934, and Tasa nipponica BoHDANOwICZ et Prószý́sKI, 1987, from Japan are reported and illustrated. The former species is new to the Japanese fauna and the latter one is recorded for the first time after the original description.
\end{abstract}

Bristowia heterospinosa was described by REIMOSER (1934) from Krakatau Islands, Indonesia. From Japan, Матsumoтo (1986) first reported a spider of the same genus as "Bristowia sp." Having examined many specimens of the Japanese spider and the type specimens of Bristowia heterospinosa, I identified the Japanese spider with the species described from Indonesia. Though Matsumoto (1986) regarded the Japanese species different from B. heterospinosa after an examination of its type specimens, I considered that both the Japanese and Indonesian specimens are within the limits of variation.

On the other hand, Tasa nipponica was described by BoHDANOwicz and PRÓSZYŃSKI (1987) based on three specimens collected in Kochi Pref., Shikoku, Japan. However, the species has never been recorded from Japan since then. Recently, I recognized two male specimens of this species collected from Ibaragi Pref. and Okayama Pref., Honshu. These two species will be described and illustrated in the present paper on the basis of the materials newly obtained.

Some of the specimens used in this paper are deposited in the collection of the National Science Museum (Nat. Hist.), Tokyo.

The following abbreviations are used: ALE, anterior lateral eye; AME, anterior median eye; PLE, posterior lateral eye; PME, posterior median eye. The distances between eyes are presented with a dash, e.g., ALE-ALE indicates distance between ALEs.

\section{Genus Bristowia ReIMoser, 1934}

Bristowia ReIMOSER, 1934, pp. 17-18. Type species, Bristowia heterospinosa, from Krakatau, Indonesia.

Diagnosis. Prosoma longer than broad with thoracic sulcus. Labium longer than broad. Anterior row of eyes recurved. The exterior ends of the maxillae not jutting forth. Legs I distinctly longer and thicker than the others, the coxae twice

1) Kanade 1099, Oimachi, Ashigarakami-gun, Kanagawa, 258 Japan

T258 神奈川県足柄上郡大井町金手 1099

Accepted December 10, 1995 
as long as broad, of the same length as the trochanters, the tibiae ventrally fringed with long erect black hairs and 2.2.2 spines, the metatarsus armed ventrally fringed with 2.2 long spines. Legs III and IV without spines.

\section{Bristowia heterospinosa REIMOSER, 1934}

(Figs. 1-14)

Bristowia heterospinosa ReImoser, 1934, pp. 17-18, figs. 1-3.-—ŻंABKA, 1985, p. 206, figs. 54-59. -SEo, 1986, pp. 23-26, figs. 1-9.—XIANJIN et al., 1993, pp. 30-32, figs. 50-57.

Bristowia sp.: Matsumoto, 1986, p. 27.-Yaginuma, Hirashima \& OKuma, 1990, p. 24.
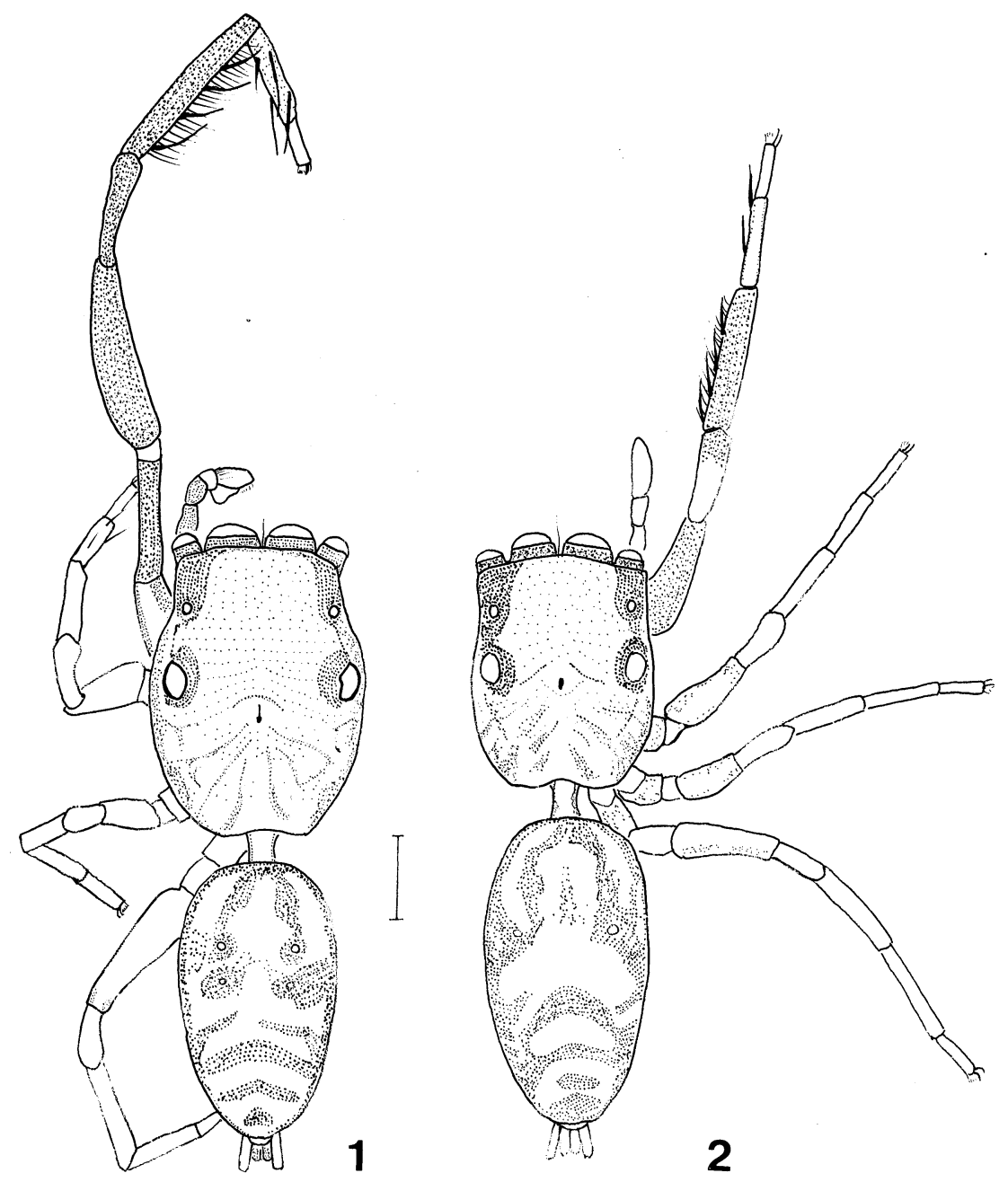

Fig. 1-2. Bristowia heterospinosa ReImoser, 1934._-1, Male, dorsal view; 2, female, dorsal view. (Scale: $0.5 \mathrm{~mm}$.) 
Specimens examined. Type series: lectotype (o) and paralectotype (우), Krakatau, Indonesia, W.S. Bristowe leg., E. Reimoser det., dom.-—Naturhistorisches Museum Wien. Other specimens: $10^{>} 5$ 우, Shimokasuya, Isehara-shi, Kangawa Pref., Japan, 4-VII-1992, K. KumAdA leg. (NSMT-Ar 3306); $20^{\urcorner} 1$ 우 nymph, same locality, 5-VI-1992, K. Kumada leg.; 1 우, rivertide of Arakawa River, Tokyo, VII-1993, K. Kumada leg.; 1우, Itayama-machi, Handa-shi, Aichi Pref., 3-IX-1993, K. OGata leg. (NSMT-Ar 3308); 107, Shinden-chô, Okazaki-shi, Aichi Pref., 30-VIII-1993, K. Ogata leg. (NSMT-Ar 3309); 140`3우, Kinkai-enden, Oku-machi, Oku-gun, Okayama Pref., 27-VI-1993, K. NoJIMA leg. (NSMT-Ar 3310); 10', Osaki-machi, Toyoda-gun, Hiroshima Pref., 16-VI-1993, Y. IHARA leg. (NSMT-Ar 3310); 202우, Tsukigahama Urauchi, Iriomote-jima Island, Okinawa Pref., 28-III-1994, A. TANIKAWA leg. (NSMT-Ar 3311).

Desciption. Measurement (in $\mathrm{mm}$ ) of specimens from Okayama Pref.; range of variation in all specimens examined in parentheses. Body length ơ3.66 (2.48-3.66), 우3.46 (2.72-3.78); prosoma length ${ }^{7} 1.70$ (1.09-1.70), 우1.44 (1.10-1.44), width o $1.28(0.86-1.28)$, 우1.06 (0.93-1.14), height ơ $0.80(0.56-0.80)$, 우 $0.64(0.61-0.64)$; opisthosoma length $0^{7} 1.79$ (1.18-1.79), 우1.76 (1.44-1.84), width $0^{7} 1.02(0.74-1.02)$, 우1.06 (0.90-1.54). Eye fields: ALE-ALE o⒈09 (0.77-1.09), 우1.01 (0.86-1.04), ALE-PLE $\sigma^{\top} 0.93(0.67-0.93)$, 우 0.82 (0.72-0.86), PLE-PLE $0^{\top} 1.18$ (0.85-1.18), 우 1.06 (0.94-1.18), ALE-PME $0^{\top} 0.40(0.32-0.40)$, 우0.37 (0.36-0.38), AME diameter ○0.36 (0.25-0.36), 우0.34 (0.31-0.34). Eyes: ALE/AME ơ $0.58(0.50-0.58)$, 우 0.57 (0.50-0.57), ALE/PLE o⒈00 (0.91-1.22), 우0.92 (0.90-1.11), PME/PLE ơ 0.23 (0.23$0.27)$, 우 $0.23(0.21-0.31)$.

Length of legs of the same specimens from Okayama Pref., as in Table 1. Spiniformation of the same specimens as in Table 2.

Male palp (Figs. 3-6). Embolus straight, tip of tibial apophysis bent. Coxa, femur and patella brown, tibia and cymbium brownish yellow.

Female genitalia (Figs. 7-9). Genital opening circular hollow, spermathecae and ducts visible through integument.

Coloration and markings (Figs. 1-2, 10-14). Male: Prosoma reddish brown, surroundings of eyes black, cephalic part with metalic shean, adherent white hairs present on lateral surfaces. Sternum brownish yellow with sparse brown hairs. Labium, maxillae and chelicerae brown. Opisthosoma dorsum brownish yellow with dark brown spots and shevrons covered with brown and whitish hairs. Opisthosoma venter brownish yellow covered with white hairs and a pair of dark longitudinal bands. Legs I: Coxa and trochanter laterally blakish brown, femur, patella and tibia dark brown with metalic shean, metatarsus brown and tarsus brownish yellow; tibia with rows of scale-like black hairs on ventral surfaces. Remaining legs brownish yellow.

Female: Same as in male, but much paler. All segments of palp brownish yellow. Leg I: femur, patella, tibia and metatarsus brown.

Distribution. Japan, Korea, China, Viet-Nam and Indonesia.

Remarks. Bristowia heterospinosa is characterized by long, slender first leg. REIMOSER (1934) originaly described that the first tibia is ventrally fringed with long erect black hairs and 2-2-2 spines. However, the spiniformation of the first tibia of the lectotype specimen is $2-2-2-1 p$ (left leg, fig. 12) or $2-2-2-1 p-1 p$ (right leg, figs. 10-11); the spiniformation of the first tibia of the paralectotype is $2-2-2-1 p$ 
H. IKEDA
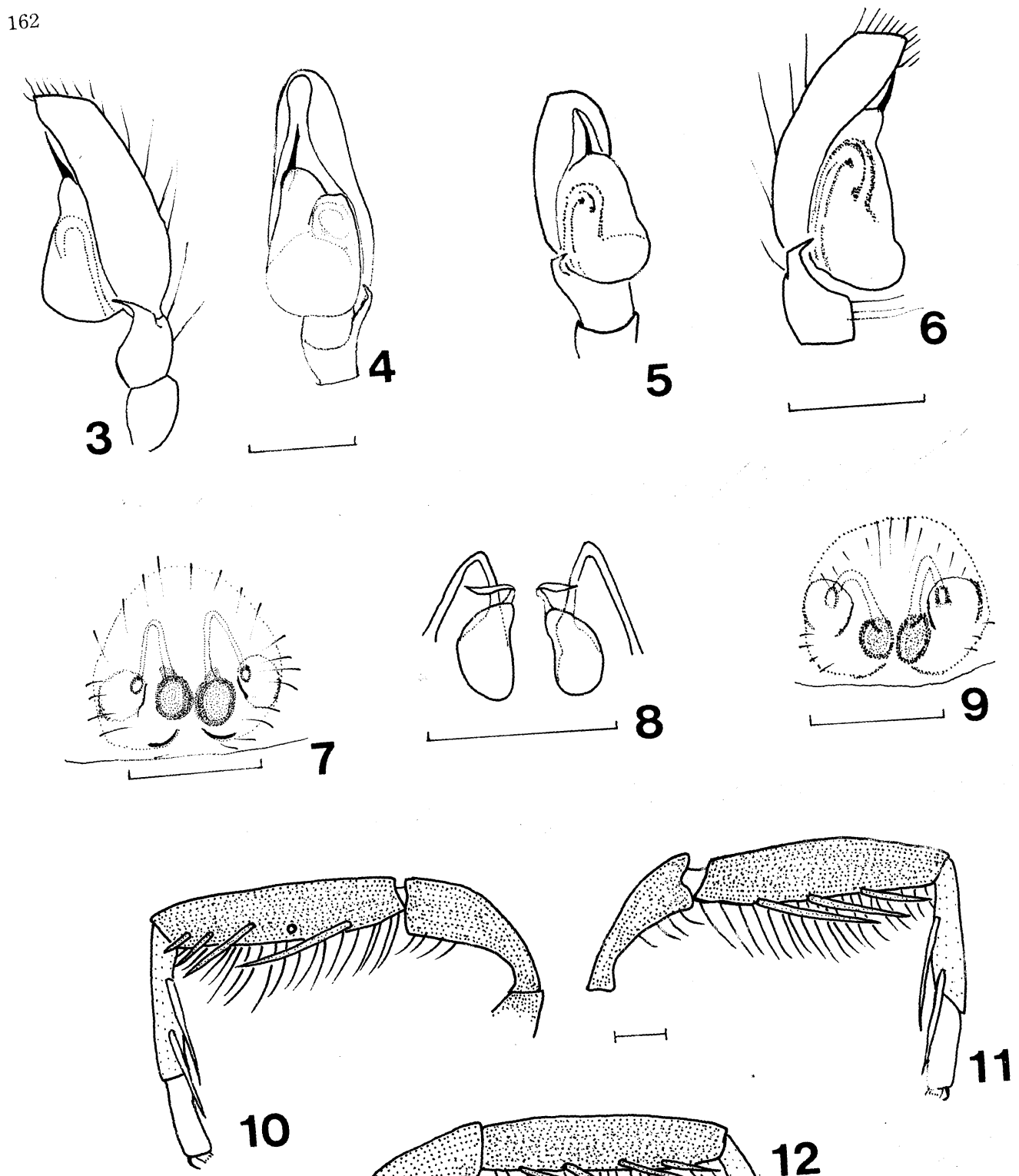

10
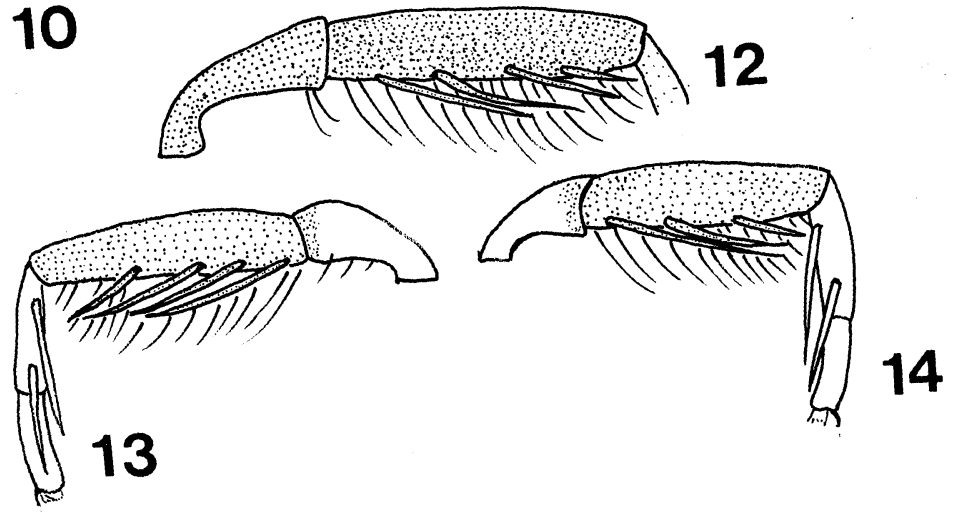
Table 1. Measurement of leg segments of Bristowia heterospinosa (in mm; ơ/우).

\begin{tabular}{ccccccc}
\hline Leg & Femur & Patella & Tibia & Metatarsus & Tarsus & Total \\
\hline I & $1.87 / 0.96$ & $1.05 / 0.56$ & $1.44 / 0.86$ & $0.83 / 0.48$ & $0.45 / 0.34$ & $5.64 / 3.20$ \\
II & $0.90 / 0.67$ & $0.46 / 0.38$ & $0.64 / 0.50$ & $0.53 / 0.40$ & $0.32 / 0.28$ & $2.85 / 2.23$ \\
III & $0.80 / 0.66$ & $0.40 / 0.34$ & $0.61 / 0.53$ & $0.62 / 0.51$ & $0.32 / 0.32$ & $2.75 / 2.36$ \\
IV & $1.09 / 0.94$ & $0.45 / 0.35$ & $0.93 / 0.75$ & $0.82 / 0.70$ & $0.40 / 0.38$ & $3.69 / 3.12$ \\
\hline
\end{tabular}

Table 2. Spiniformation of legs of Bristowia heterospinosa (dorsal/ventral; none $=$ no spine, $\mathrm{p}=$ prolateral, $\mathrm{r}=$ retrolateral).

\begin{tabular}{rll}
\hline Leg & \multicolumn{1}{c}{ Tibia } & Metatarsus \\
\hline I oフ & none $/ 2-2-2-1 \mathrm{p}-0$ & none $/ 2-2$ \\
우 & none $/ 2-2-2-1 \mathrm{p}-0$ & none $/ 2-2$ \\
II 구 & none $/ 0-1 \mathrm{r}-0$ & none $/ 2-2$ \\
우 & none $/ 0-1 \mathrm{r}-0$ & none $/ 2-2$ \\
\hline
\end{tabular}

Other segments of legs I and II and other legs have no spine.

(right leg, figs. 13-14).

Small differences in sexual organ are recognized between the Japanese and the Indonesian specimens, for example, the length of duct of female genitalia and the shape of retrolateral tibial apophysis of male palp.

\section{Genus Tasa WesoKowsKA, 1981}

Tasa WesoŁowsKa, 1981, pp. 157-158. Type species, Thianella davidi Schenkel, 1963, Hantschong-fu (probably Hangzhou), China.

Diagnosis. Prosoma rather elongate, flat and not much elevated; pigmentation devoid of distinctly contrasting features. Male palp characteristics: Diamondshaped bulbs is distally prolonged by thick embolus bent laterally and then medially (hook-shaped). Tibial apophysis basically biramous with additional small teeth. Femur of pedipalps ventrally with triangular protuberance.

\section{Tasa nipponica BoHDANOWICZ et PRÓSZYŃSKI, 1987}

(Figs. 15-20)

Tasa nipponica Bohdanowicz et PrószyŃski, 1987, pp. 143-144, figs, 300-303.—- Seo, 1992, p. 183, figs. 13-16.

Specimens examined. 10', Shishitsuka Ôike, Tsuchiura-shi, Ibaragi Pref.,

Figs. 3-14 (on page 162). Bristowia heterospinosa ReIMOSER, 1934.-3-4, 7-8, Specimens from Okayama Pref., Japan; 5-6, 10-12, lectotype specimen; 9, 13-14, palalectotype specimen. 3,6, Male palps, retrolateral view; 4-5, male palps, ventral view; 7, 9, epigyna; 8 , female genitalia, dorsal view; 10, 13, right first legs, prolateral view; 11, 14, right first legs, retrolateral view; 12, left first leg, prolateral view. (Scales: $0.2 \mathrm{~mm}$.) 


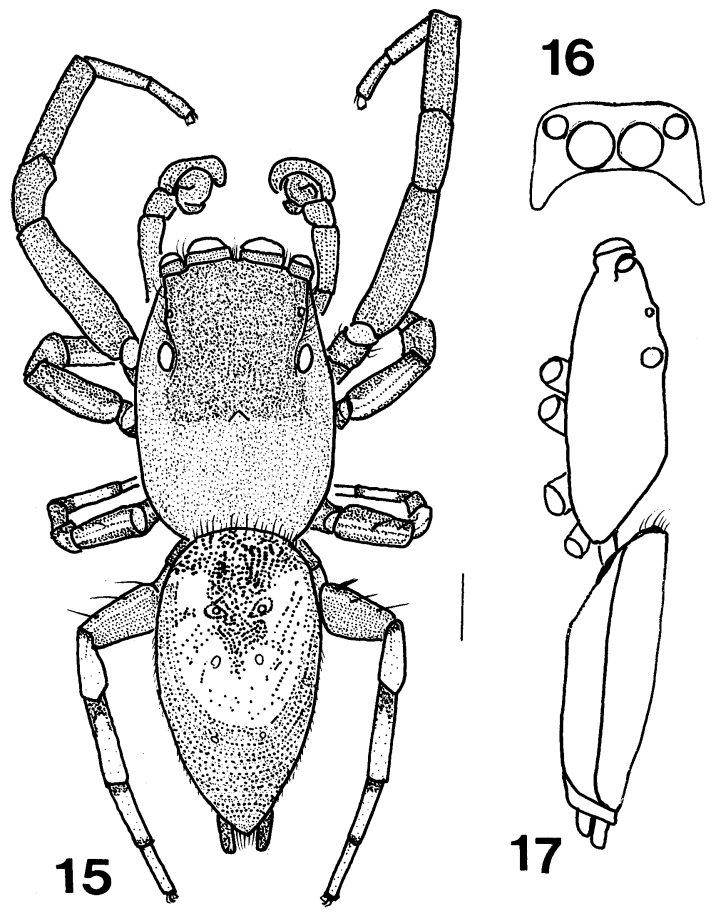

Figs. 15-17. Tasa nipponica BohdanowiCz et PrószyŃskı, 1987—15, Male, dorsal view; 16 , same, frontal view of prosoma; 17, same, lateral view. (Scale: $0.5 \mathrm{~mm}$.)
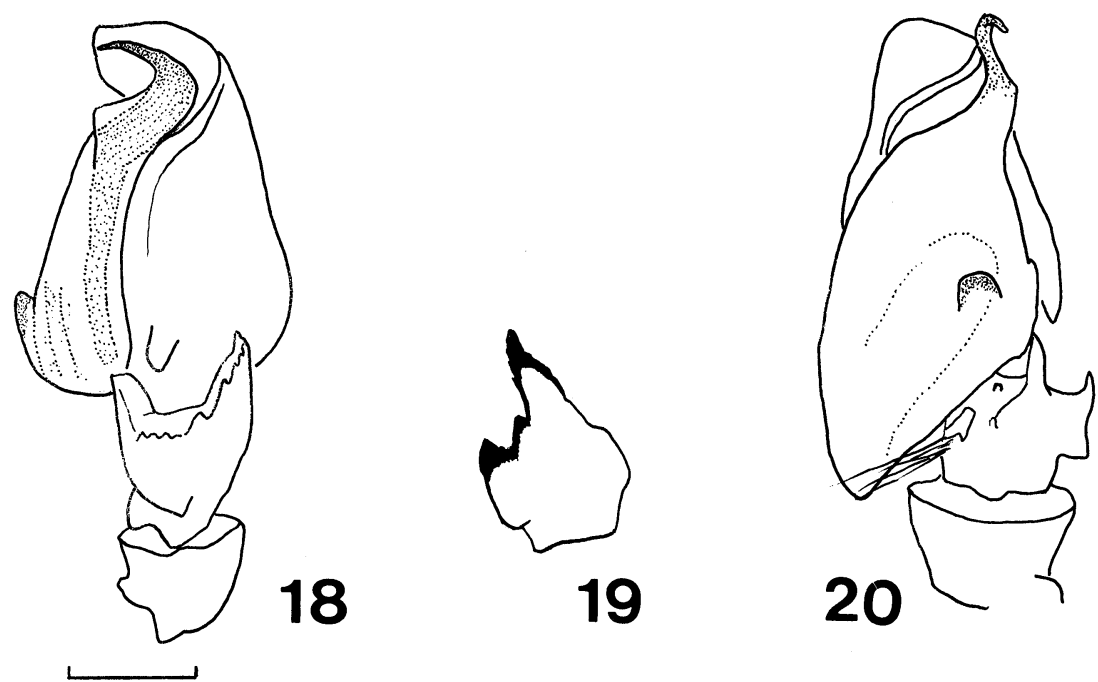

Figs. 18-20. Tasa nipponica BoHDANOwiCZ et PrósZYŃSKI, 1987—18, Male palp, retrolateral view; 19, tibial apophysis of male palp, dorsolateral view; 20, male palp, ventral view. (Scale: $0.2 \mathrm{~mm}$.) 
Table 3. Measurement of leg segments of Tasa nipponica (in mm).

\begin{tabular}{ccccccc}
\hline Leg & Femur & Patella & Tibia & Metatarsus & Tarsus & Total \\
\hline I & 1.36 & 0.64 & 0.88 & 0.56 & 0.40 & 3.84 \\
II & 0.83 & 0.48 & 0.62 & 0.45 & 0.30 & 2.68 \\
III & 0.82 & 0.42 & 0.48 & 0.53 & 0.32 & 2.57 \\
IV & 1.00 & 0.50 & 0.70 & 0.64 & 0.40 & 3.24 \\
\hline
\end{tabular}

Table 4. Spiniformation of legs of Tasa nipponica (dorsal/ventral; none $=$ no spine, $\mathrm{p}=$ prolateral, $\mathrm{r}=$ retrolateral).

\begin{tabular}{clll}
\hline Leg & \multicolumn{1}{c}{ Femur } & \multicolumn{1}{c}{ Tibia } & \multicolumn{1}{c}{ Metatarsus } \\
\hline I & $0-1-1-0 /$ none & none $/ 0-1 \mathrm{p}-1 \mathrm{p}-1 \mathrm{p}$ & none $/ 0-2-2$ \\
II & $0-1-1-1-0 /$ none & none $/ 0-1-1-0$ & none $/ 0-2-2$ \\
III & $0-1-1-2-0 /$ none & none $/ 1 \mathrm{p}-1 \mathrm{p}$ & $0-2 / 0-0-2$ \\
IV & $1-1-1-0 /$ none & none $/ 0-1 \mathrm{p}-2$ & $0-2 / 0-2-2 \mathrm{p} 2 \mathrm{r}$ \\
\hline
\end{tabular}

Japan, 26-VI-1995, Y. Kudo leg. (NSMT-Ar 3312). 107, Sakazu, Kurashiki-shi, Okayama Pref., 28-V-1995, K. NoJIMA leg.

Description based on the male newly obtained from Ibaragi Pref. Measurement (in $\mathrm{mm}$ ). Body length 3.89 ; prosoma length 1.89, width 1.31 , height 0.71 ; opisthosoma length 1.95, width 1.28. Eye fields: ALE-ALE 0.80, ALE-PLE 0.67, PLE-PLE 0.98, ALE-PME 0.34, AME diameter 0.32; ALE/AME 0.50, ALE/PLE 1.00, PME/PLE 0.20.

Length of legs of $10^{7}$ (NSMT-Ar 3312) as in Table 3. Spiniformation of same specimen as in Table 4.

Male palp (Figs. 18-20). Typical for the genus; embolus hook-shaped, thick, tibial apophysis biramous, with additional small teeth, bulbs lozenged with protuberance. Femur, patella and tibia brown, cymbium dark brown.

Coloration and markings (Figs. 15-17). Male: Cephalic part of prosoma black, thoracic part of prosoma blackish brown, both covered with whitish hairs, adherent black setae present on margins of anterior eyes and beneath the PLEs. Clypeus very narrow (Fig. 16). Sternum and labium black, covered with white hairs, maxillae blackish brown with pale margin, chelicerae dark brown. Opisthosomal dorsum black with black hairs and whitish hairs, brownish yellow at the middle, anterior margin with many white setae. Venter of opisthosoma black with white hairs. Leg I: femur, patella and tibia black, metatarsus and tarsus brown. Leg II : femur black, tarsus brownish yellow, other segments brownish yellow proximally with black bands. Remaining legs with same colour as in leg II.

Female: Unknown.

Distribution. Japan (known only from Ibaragi, Okayama and Kochi Prefectures).

Remarks. Tasa nipponica closely resembles Tasa davidi (SCHENKel, 1963), but can be distinguished from the latter by the shape of ventral branch of tibial apoph- 
ysis of male palp and colour of legs. In T. davidi, branch is needle-shape and legs are yellow (SCHENKel, 1963; WeSOŁOWSKA, 1981; BoHDANOWICZ \& PrósZYŃSKI, 1987; XiAnJin et al., 1993).

\section{Acknowledgements}

I wish to express my hearty thanks to Dr. Hirotsugu ONO, National Science Museum (Nat. Hist.), Tokyo, for his constant guidance and for critically reading the manuscript of this paper, to Dr. Jürgen Gruber, Naturhistorisches Museum Wien, Austria, for loaning the type specimens, to Prof. Seiji Matsumoto, Kyorin Univ., for his advice, and to Ms. Yasue Kudo, Chiba, Mr. Akio TaniKawa, Kanagawa, Mr. Ken-ichi Kumada, Mie, Mr. Kiyoto Ogata, Aichi, Mr. Ko-ichi NoJima, Okayama, and Mr. Yoh Ihara, Hiroshima, for offering and loaning the specimens used in this paper.

摘 要

日本産ハエトリグモのうち，記録の少なかった 2 種, Bristowia heterospinosa ReIMOSER, 1934 (マッモトハエトリ) および Tasa nipponica BoHdanowicz et PrószyŃsKI, 1937 (トサ ハェトリ）を新たに得られた標本にもとづいて記載した。マッモトハェトリは種名未決定 であったが，タイプ標本との比較にもとづいて，インドネシアから記載された上記の種に 同定した。同種は日本新記録である。トサハエトリは最初の発見以来，32 年ぶりに再発 見された。

\section{References}

Bohdanowicz, A., \& J. Prószyński, 1987. Systematic studies on East Palearctic Salticidae (Araneae), IV. Salticidae of Japan. Ann. zool. Warszawa, 41: 43-151.

Matsumoto, S., 1986. Bristowia sp. from Japan. Atypus, (87): 27.

Platnick, N. I., 1989. Advances in Spider Taxonomy, 1981-1987. 673 pp. Manchester University Press.

Reimoser, E., \& W. S. Bristowe, 1934. The spiders of Krakatau. Proc. zool. Soc. London, 1934: 11-18.

Schenkel, E., 1963. Ostasiatische Spinnen aus dem Museum d'Histoire Naturelle de Paris. Mem. Mus. natn. Hist. nat. Paris, (A, Zool.), 25: 1-481.

SEo, B. K., 1986. One unrecorded species of salticid spider from Korea (II). Korean Arachnol., 2(1): 23-26.

, 1992. Four newly recorded species in the Korean salticid fauna (II). Ibid., 7: 179-186.

Xianjin, P., X. Liping \& X. Xiaoqin, 1993. Salticids in China. 270 pp. Hunan Normal Univ. Press.

Wesolowska, W., 1981. Redescription of the E. Shenkel's East Asiatic Salticidae (Aranei). Ann. zool. Warszawa, 36: 127-159.

Yaginuma, T., Y. Hirashima \& C. Okuma, 1990. Spiders. Etymology of their Scientific and Japanese Names. 287 pp. Kyushu Univ. Press, Fukuoka. (In Japanese.)

ŻABKA, M., 1985. Systematic and zoogeographic study on the family Salticidae (Araneae) from Viet-Nam. Ann. zool. Warszawa, 39: 197-485. 